\title{
Context-Specific Influencing Factors Within A Transfer Of Innovation From Corporate Incubators
}

\author{
Prof. Gunther Schuh. \\ Department of Technology Management \\ Fraunhofer Institute for Production \\ Technology IPT, \\ Aachen, Germany
}

\author{
Florian Vogt \\ M.Sc. M.Sc. \\ Department of Technology Management \\ Fraunhofer Institute for Production \\ Technology IPT, Aachen, Germany
}

\author{
Dennis Maurer \\ M.A. \\ Department of Technology Management \\ Fraunhofer Institute for Production \\ Technology IPT, Aachen, Germany
}

\begin{abstract}
Corporate incubators are used to generate innovation outside existing corporate structures. However due to strategic aspects, the exploitation and commercialization of these innovations are mainly done through the corporate. The integration of the innovation within existing corporate structures thereby is a major challenge, since neither sufficient research results on this topic nor sufficient orientation knowledge on the basis of operational practice were generated so far. This research paper contributes to solve these challenges through the development of a model to describe context-specific influencing factors influencing the transfer process between corporate incubator and its parent company. Within the paper a framework which covers all relevant factors is derived. According to the sender-receiver model the framework consists of three relevant context factors: the corporate incubator, the parent company and a comprehensive perspective. Based on a comprehensive literature search, a total of 10 aggregated transfer-relevant and context-related influencing factors could be identified, defined and described regarding their transfer impact.
\end{abstract}

Keywords-Corporate incubator, innovation, transfer process, innovation transfer, influencing factor

\section{INTRODUCTION}

Accelerating product life cycles, changing customer behavior and a continuously changing market environment force established companies to constantly challenge and renew their own product portfolio [1]. New technological possibilities and changing business models increase the need for radical innovations within and outside existing markets in addition to incremental innovations [2]. The development of such future-oriented, new developments is essential in order to actively shape transformation processes on the market and to be able to sustainably ensure the preservation of economic success in the long term [3].

However, established companies often find it difficult to develop radical innovations. This competitive deficit is primarily due to the hurdle of the so-called innovator's dilemma, which describes the challenge of being able to drive forward new disruptive developments in addition to the continuous improvement of existing products. Established companies often lack creativity and organizational flexibility to do so [4]. They prefer the risk-averse alternative of the market-oriented improvement of established technologies [5].

To counteract this, successful companies are increasingly relying on organizational ambidexterity [6]. Through the organizational separation between exploration and exploitation activities, innovation barriers can be avoided within the development of radical innovations [7].

The setup of a corporate incubator is one possibility of implementing an ambidexterity organization. As a separate innovation path this type of organizational unit attempts to create an environment in which radical innovations find the best possible development conditions [8; 69]. Similar to a startup [9], corporate incubators provide flatter hierarchies, shorter decision-making paths and generally more flexible organizational structures. The development of radical business models, technology and product innovations outside existing corporate structures is promoted [4;27].

The exploitation of the innovations developed in the corporate incubator is of great importance. Innovations are either brought to market independently through the incubator or transferred back to the parent company during a certain phase of the development process. SCHUH ET AL. [10] found in their study on agile invention that half of the companies surveyed use external innovation paths and that more than $80 \%$ of innovations developed within the corporate incubator are transferred to the parent company. Innovation transfers are especially pursued if the innovation is of high strategic value for the company.

However, due to the lack of interaction, different structures, processes, speeds and attitudes, it is precisely this integration of innovation from corporate incubator in the structures of the parent company that poses enormous practical challenges [11]. Incubators usually do not work according to classical business processes. It is therefore difficult to assign the output to existing internal process structures [12]. Furthermore different cultures and mindsets of the employees must be taken into account during the transmission. The literature so far lacks of a detailed analysis and systematic approach for the described problem. 
A detailed approach to systemize the transfer process of innovations from corporate incubator to the parent company is therefore necessary. Especially the context-specific influence of the different transfer entities has so far only been insufficiently scientifically examined, so that even within practice there is only a reduced amount of orientation knowledge. The negligence of these aspects can lead to tensions and contradictory transfer requirements, which in total lead to a decrease in innovation potential and the probability of success in general [5]. Therefore the aim of this paper is to derive a description model of context-specific influencing factors on the transfer of innovations from corporate incubators. It will be discussed which transferrelevant influencing factors exist and how these influence the transfer process into the parent company. A proposal how to design the transfer process based on the context specific influencing factors is not part of this paper.

\section{LITERATURE REVIEW}

The specific transfer process between corporate incubator and its corporate is so far only less discussed in literature. To derive situation specific context factors for the specific transfer process, different aspects will be examined for their relevance. At first existing approaches to describe transfer processes will be examined in literature to identify a suitable transfer process. Following relevant aspects of the corporate incubator as well as the corporate will be discussed. To ensure the scientific aspect of this paper, requirements for the derivation of context specific influencing factors will be shown at the end of this section.

\section{A. Innovation transfer}

The sender-receiver approach from SHANNON AND WEAVER [13] is seen in literature as the basis for all kind of transfer processes, therefore it can be also applied on the transfer of innovation. According to ALBRECHT AND LAMBKE [14], two partial actions are required within this transfer. Knowledge must be passed on by the sender so that the knowledge can then be used by the recipient. This dichotomy is also supported by PROBST ET AL. [15]. KROGH AND KÖHNE [16] divide the transfer process into the initiation, knowledge flow and integration phase. There are different approaches within the literature to describe the transfer of innovations between different entities. Generally in literature there is a differentiation between knowledge transfer, technology transfer and research transfer.

Knowledge transfers is a major aspect within the knowledge management research. Knowledge is seen as the most important aspect for corporate to achieve competitive advantages [16; 17]. According to POLANYI it can be distinguished between explicit knowledge, which can be documented and tacit knowledge, which relates to personal experiences and therefore is hard to document [18]. The knowledge management research therefore focuses on the question how to transfer these different forms of knowledge from the sender to the receiver and how to applicate it within the receiver [16; 19].

Technology transfer on the other side mainly deals with the transfer of technical competences [20]. The research is closely linked to the area of knowledge transfer, however only focused on the transfer of technological knowledge.
Especially the integration within the existing application at the receiving unit is a major aspect within the technology transfer [20].

Research transfer is a specific research area, which focusses on the transfer between research institutes and corporates. According to MEIBNER research transfer therefore can be defined as the application of research results from universities or research institutes at external partners [19].

Within the transfer of innovation from corporate incubators the transfer object is not clearly defined. It can contain knowledge or technology within or outside the company's core business. Therefore all approaches within the field of transfer process will be considered within the derivation of a specific transfer process for corporate incubators.

\section{B. Corporate Incubator}

Within this investigation, the transmitter knowledge carrier is a corporate incubator. What all types of incubators have in common is that they support entrepreneurs in an early development phase of their businesses in order to reach the best growth potential $[21 ; 22]$. In organizational theory, such workforces work in an organic structure [23]. This implies a generally oriented workforce and is defined by selforganization, a high ability to improvise, a lack of formalism and a small number of hierarchical levels [23; 24; 25]. They can react dynamically, flexibly and individually to necessary changes in development processes and better master challenges through lateral coordination, comprehensive communication and an innovation-friendly error culture [26; 27].

The specific form of the corporate incubator is supported by large established organizations, so-called corporates, which establish an external organizational unit for the development of radical innovations in order to overcome their entrepreneurial inertia and increase their own innovative strength through diversification [22; 28; 29]. However, the creation of a separate innovation path in the form of a corporate incubator often implies structural, procedural and spatial autonomy, so that own workspaces, task allocations, roles and reporting relationships are different from the organizational structure of the mother [30]. They often have numerous self-governing powers and a comprehensive freedom of action in order to enable a detached innovation development [31; 32]. Corporate Incubators are therefore autonomously operating company units on the basis of previous terminological descriptions, which promote the generation, further development and commercialization of radical innovations by providing an innovation path separate from the existing structures of the parent organization [29]. This definition will be followed within this paper.

\section{Established parent company}

Parent companies which operate a corporate incubator are mainly well established within a market. Within the parent organization, employees are familiar with processes, structures and competencies [33; 34]. A long grown corporate culture as well as strong stakeholder relationship are already established. In terms of organizational structure, the focus is on solving problems in routine tasks [35]. Thus, continuous rationalization tendencies as well as the predominance of 
administrative processes and formal decision-making paths are characteristic in bureaucratic process organization [34].

\section{Context-specific influencing factors}

Influencing factors are those descriptive characteristics that are in a direct relationship with the transfer of innovation. They have a substantial and lasting influence on the transfer based on their specific characteristics. These influencing factors and their characteristics are described within a specific context. This means that the present study is based on the fact that decisions, actions or statements take place in a particular context [36]. Context is defined as a specific environment or a combination of factors that have a connection in terms of content.

\section{RESEARCH METHODOLOGY}

The system-theoretical approach according to ULRICH enables a cross-disciplinary investigation of management and organizational problems through its "interdisciplinary openness" [37]. Due to its heuristic function, it allows the recording and representation of all context-specific influencing factors and characteristics on transfer processes.

Therefore, the research methodology of this study is oriented towards the qualitative, explorative and systematic research process for applied sciences according to ULRICH [38]. Following the goal of applied sciences, practice-relevant approaches with the goals of designing social and technical systems and supporting decision-making processes are examined [39]. In the context of this paper, a practical problem is analyzed and described. The developed model enables to solve part of the challenges within the transfer of innovation from corporate incubators and to ensure an implementation of the transfer object within the corporate. Both the start and the end of the research have a practical relevance.

This publication will consider the first five steps (A-E) of the research process shown in figure 1 , which compromises in total seven consecutive steps. Due to the scope of this publication, the examination of the model as well as the consulting in operational practice will not be part of this research paper.

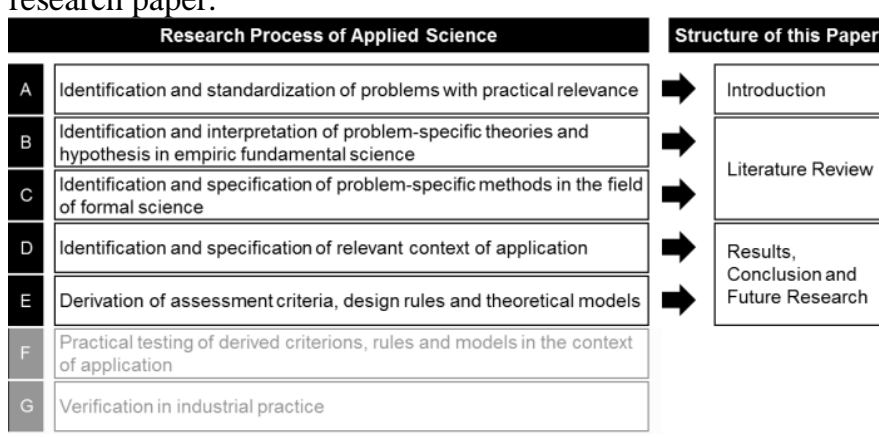

Fig. 1. Research Process of Applied Sciences [38]

The research process begins according to the practical context with empirical-inductive research. Here, the practicerelevant conditions and problems are examined in order to identify a deficit existing in theory and to present the need for research. This is shown in the introduction of the publication and step A of the research process.

Terminological-descriptive fundamentals are then explained, which limits the scope of consideration and identify problem-relevant theories and procedures on the basis of current literature. These findings from steps $\mathrm{B}$ and $\mathrm{C}$ are discussed in a literature review and form the basis for the application context

With the aid of analytical-deductive derivations a model for the innovation transfer is presented and a framework for the derivation of context specific influencing factors is developed. Based on this framework, relevant influencing factors will be identified and their impact on the transfer process will be evaluated. Finally a summary of the study results as well as an outlook on further research desiderata follows.

The steps $\mathrm{F}$ and $\mathrm{G}$ described in the research process of applied science, which include empirical-inductive validation will not be part of the present study, as already described above.

\section{THE MODEL OF INNOVATION TRANSFER FROM CORPORATE INCUBATORS}

The presented work contributes to the described problem how innovation from corporate incubators can be transferred to its parent organization. To address this problem, the author develops a model of innovation transfer from corporate incubators. The aim of the model is to take all relevant factors within a transfer decision into account and to help corporates to adapt the transfer process based on situation specific aspects. [40] The model is displayed in figure 2 .

Therefore the model of innovation transfers covers the aspects of the transfer object, a generic transfer process as well as the situation specific aspects of the corporate incubator and the corporate. Requirements for the transfer process will be derived and based on identified design options, a suggestion for the design of the transfer process can be made.

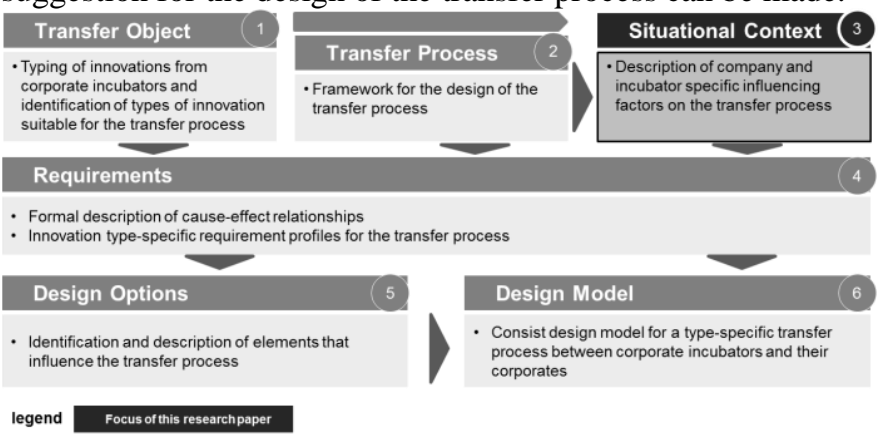

Fig. 2. Model of innovation transfer and the focus of this paper

The following research paper mainly focuses on the situational context of the developed model. The goal is to identify situation specific aspects within the involved entities that influences the transfer process. Therefore a framework for the influencing factors is developed and the influencing factors are identified and described.

\section{FRAMEWORK FOR THE CONTEXT-SPECIFIC INFLUENCING FACTORS}

To develop a framework for the context-specific influencing factors within a transfer process, the relevant contexts have to be identified first. Based on the senderreceiver model of SHANNON AND WEAVER [13] and the transfer framework of ROHRLACK [41] the context-specific framework for a transfer process between corporate incubator and its corporate will be derived. 
Within the sender-receiver model, the sender is seen as the source of the transfer objects and due to its characteristics mainly determines the transfer process. In the addressed problem the corporate incubator is the source of the innovation and its design and structure must be considered within the framework. In addition to the sender, the receiver has an elementary influence on the transfer process. Depending on the existing corporate structures the transfer process has to be designed specifically. Accordingly, the context of the parent company, as the recipient entity, will be integrated within the framework as well. Shannon and Weaver also mention in their model possible noise sources, which effect the transfer process between a sender and a receiver. Regarding the specific transfer process, comprehensive context factors, which can not be assigned either to the sender or the receiver will be included into the framework. The framework for the context specific influencing factors within a transfer process between corporate incubator and its corporate is presented in figure 3 .

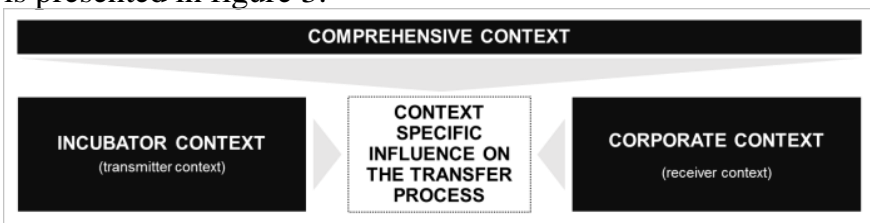

Fig. 3. Framework model for the description of factors influencing the transfer of innovation

\section{CONTEXT SPECIFIC INFLUENCING FACTORS}

Based on the previously defined framework, all relevant design parameters are to be examined in the first step. For this purpose, all descriptive characteristics of corporate incubators and their parent organization have been elaborated in a comprehensive literature search. Especially LAU's work which focusses on the design of corporate incubators displayed many description factors [42]. These were added and adapted through different research studies.

Subsequently, all descriptive characteristics were examined consecutively for relevance to innovation transfer. The selection was based on an analytic-deductive method of intensive literature study as well as empiric-inductive analysis based on own findings of the authors in different industrial projects within the field of corporate incubation.

A total of 54 descriptive characteristics relevant to the transfer of innovation were worked out. These were then examined for content redundancy and correlation across contexts in order to finally develop consistent, aggregated influencing factors. Redundant are influencing factors if they can be omitted without loss of information. The components of an influence factor are correlatively consistent if they are firmly connected and can be differentiated from each other on the basis of mutual influences. The majority of the influencing factors were developed on the basis of various individual description characteristics. The results of this review are presented below. The final influencing factors are integrated into the framework model, defined and described based on their transfer relevance

Within the next chapter, the factors of the model are described and their impact on the transfer process is examined.

\section{A. Context of the Corporate Incubator}

Within the context of the corporate incubator, five influencing factors were identified: the temporal development focus, the location, the organizational anchoring, the legal form and the involvement of the corporate (see figure 4). These factors will be described in detail within the following chapter.

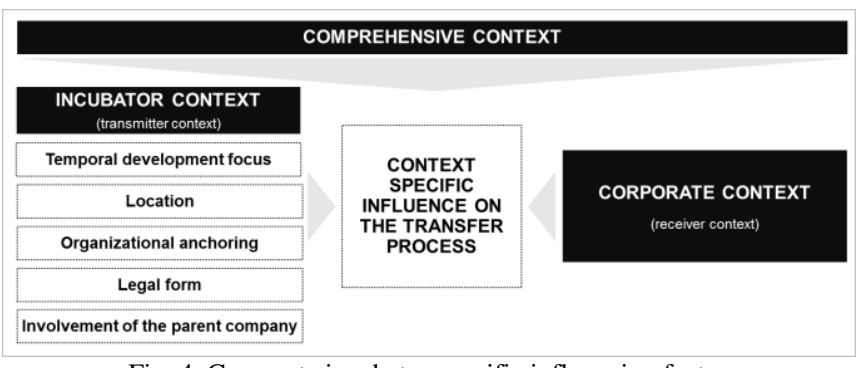

Fig. 4. Corporate incubator specific influencing factors

1) Temporal development focus: The innovation process can be divided in different process steps [34; 43]. At the beginning of the innovation process ideas are generated within a creativity oriented phase. Within the development phases these ideas are sharpened and concepts or prototypes are developed. The last step is to scale and commercialize the innovation project by integrating the innovation into the production and marketing processes [44; 45].

The temporal development focus of a corporate incubator describes in which process step the incubator is mainly active. Due to its startup like organizational structure, corporate incubators have the greatest potential especially in early process phases [11]. However it is possible that a corporate incubator acts within multiple phases.

For the transfer process the temporal development focus defines in which state the innovation is transferred into the organization. Corporate incubators that mainly focus on creativity the phase, integrate the innovation at an early stage. The more the focus shifts to the development or commercialization phase the more mature is the innovation within the transfer process. The maturity of the transfer object defines the scope of the transfer process. The complexity of innovations in the early stage is yet not high, and only little specific know how was yet build up. However transferring an idea too early can lead to a lack of acceptance within the corporate and increases the chance that the potential of the idea is not fully exploited. More mature innovations already have proven their market relevance or technical feasibility so that it is easier to convince employees within the corporate. However the actual transfer is more complex due to the fact that a lot of specific knowhow and competences need to be transferred.

2) Location: The geographical location of a corporate incubator can be different to the location of the parent company. Therefore the location of the incubator describes the distance between these two entities. Corporate incubators choose their location mainly based on strategic issues, e.g. they want to be close to startups or tech hubs. This influencing factor can be divided into ideal typical forms of the same location in terms of structural integration of the incubator into the building of the parent company, close to the company, i.e. 
within walking distance of less than $2 \mathrm{~km}$ and far away from the company.

It can be seen that an incubator placed inside the building or within walking distance of the parent organisation tends to be better known by employees; they have appropriate knowledge of its existence and purpose and can provide the foundation for a solid, cross-entity network [41; 46]. The form of communicative coordination instruments also changes with great geographical distance $[41 ; 47]$. The need for personal interaction as described by ATHANASSIOU AND NIGH [48] or DE MEYER [49] which is necessary for building social relationships can only be met by two far-flung business units through increased time requirements and increased costs $[41 ; 50]$.

Differences in the forms of communication are also associated with its intensity. The regular exchange between the departments is intensified if the incubator is nearby. The probability of informal regular exchanges while eating in the canteen or during a coffee break is significantly higher. It was confirmed that less established personal relationships between transfer partners significantly slow down the transfer of very complex technologies, due to more frequent communication and coordination problems $[67 ; 68]$.

In addition to their influence on costs and speed, these challenges also influence the performance of a innovation transfer. Transfers between separated entities are accompanied by a risk of higher loss of information. Less information results in more room for interpretation, so that the concrete identification of the innovation-relevant knowledge elements is hindered. BouTELLIER ET AL. [24] confirm that the amount of information exchanges does not increase linearly but exponentially with increasing distance between entities. Furthermore limited information can lead to a rejection of innovation from corporate incubators. Corporate employees find the innovations from corporate incubators too less attached to their current business and refuse an intensive collaboration.

3) Organizational anchoring: The organizational anchoring in the parent company is defined by the hierarchical integration of the incubator. The corporate incubator can be anchored decentral, e.g. divisionally and thus work for a specific division of the parent organization, or functionally, i.e. at a functional area. In contrast to this is the central anchoring, i.e. the integration as a staff unit to the top management, which reports directly to the management at the highest hierarchical level.

A central incubator predominantly pursues the company's overall operational goals, whereas a divisional or functional incubator pursues sector-specific goals [42]. Overall innovation transfers tend to be more complex, as they trigger changes beyond company divisions. Their broader integration can usually be characterized as more cost- and time-intensive. Linked to this, the organizational anchoring determines the extent to which the parent company is involved [42]. Decentralized incubators develop innovations for a specific division or department. An intensive involvement of the receiver is given, since the innovation is meant to be transferred to the business unit. The incubator is integrated into an existing business unit, its targets are linked to the business unit and has a correspondingly higher operational relevance [32], so that knowledge flows and innovation integrations can be processed more efficiently and more appropriately for the target group. In this context, there are often direct contacts across entities who are involved in the innovative project team. The higher basic understanding in the sense of increased prior knowledge about the incubator's activities supports the knowledge absorption within an innovation transfer $[32 ; 52]$.

With regard to central incubators, it must be noted that they usually develop without intensive involvement of recipient departments and must therefore first find a contact persons within the divisions. The search for a recipient, the processes of knowledge flow as well as innovation integration can therefore slow down the speed of the transfer process.

Central anchoring allows for greater assertiveness throughout the company in the case of innovation transfers and the allocation of necessary cross-divisional personnel due to the more comprehensive decision-making powers of top management. Intraorganisational resistance, which is highly likely to occur in radical innovations, can be dealt with by a central, hierarchically higher management unit $[33 ; 53 ; 54]$.

4) Legal form: The legal form describes the extent to which a corporate incubator is formally and legally connected to its parent company. On the one hand, an internal incubator can be part of the parent company, usually as an independent department, on the other hand it can also act as a legally independent company with its own legal form. [43].

A corporate incubator that is formally separated from its parent company, is more likely to have individual support structures such as HR, IT or purchasing. The missing superordinate administrative or support structures lead to the fact that a reintegration of innovation objects into the processes of the parent company is more difficult. The "closer" the incubator is to its parent organization, the higher is the probability of compatibility of some business processes between the two entities. This means that, own support structures of the corporate incubator are accompanied by higher resource costs for the coordination of necessary transfer activities.

On the other hand, the decision-making autonomy increases with a legally independent incubator. This leads to a higher risk of reducing the transfer speed due to a more complex decision making process e.g. in planning or standardization efforts of the transfer. A high degree of decision-making sovereignty can lead to more resistance within the cooperation and to a lack of coordination within the innovation transfer. For example, based on studies of subcompanies of large corporations, it is conceivable that isolation tendencies could rise on the basis of the different company names or legal form, which leads to aversion against ideas from the different entity [54].

5) Involvement of the parent company: The involvement of the parent company describes the degree of how much the corporate is involved within the operative and strategic activities of the corporate incubator. The amount of involvement varies based on the innovation or the incubator setup. Corporate incubators can be run totally independently 
from the current business, which means without any involvement of parent company. However more commonly is that the corporate is involved somehow within the corporate incubator. Corporates can be strategically involved so that the corporate management is aware of the ongoing projects within the incubator and is involved in the decision making process. If a strong operative involvement is preferred, employees from the corporate are integrated directly within the innovation process. Generally that means that these employees work at the corporate incubator for the duration of the innovation project.

A strong involvement of the corporate is helpful within the transfer process. If corporate employees are integrated within the innovation project, an existing network can be used that positively influences the communicative interaction between the entities and reduces interface problems. These employees know the processes and contacts within the parent company, so that such a cooperation improves speed and reduces coordination costs [36]. In addition, it can be deduced that the employee's function or divisional affiliation provides an existing innovation-relevant knowledge that can be linked with new knowledge to be integrated through the transfer. This enables innovation-relevant content to be understood more efficiently and tends to reduce the loss of information.

SCHRÖDER [54] also found that the individual member's willingness to participate in the project is positively influenced. This is based on the fact that employees in multifunctional teams discuss openly and exchange comprehensive information. A cross-entity interdisciplinary workforce allows an increased problem-solving competence [55], which is critical for success within innovation transfers. This indicates that a workforce composed of both entities is more successful in developing and transfer radical innovations.

\section{B. Context of the Corporate}

Four relevant influencing factors for the transfer process were identified within the context of the parent company: Needed competences, organizational flexibility, management support and the corporate culture (see figure 5). The factors are described and analyzed based on their transfer relevance.

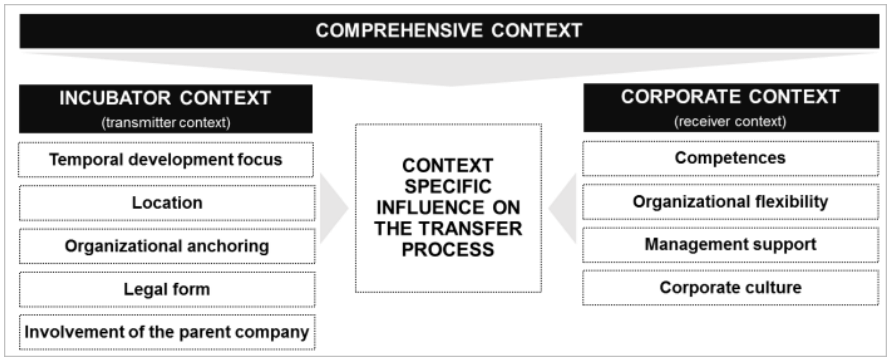

Fig. 5. Corporate specific influencing factors

1) Competences: Necessary competences are understood as skills, knowledge and methods of thinking which are linked to the transfer of knowledge or the innovation which is to be transferred. The capability to absorb new competences is discussed within the approach of Absorptive Capacity [56]. Absorptive capacity is defined as the necessary cognitive perception, processing and learning ability of the workforce to absorb new knowledge in order to participate efficiently in the transfer of innovation. The aim is to enable employees to absorb knowledge with the help of their cognitive structures and cumulate it more efficiently with existing knowledge [41]. For the context of the innovation transfer a distinction can be made if the needed competences do exist or not.

HAMEL [57] stated in his work that "If the skill gap between partners is too great, learning becomes almost impossible", since it is impossible for the recipient "[...] to identify, if not retrace, the intermediate learning 'steps' between its present competence level and that of its partner". The more diverse, broader and deeper the individual prior knowledge is, the more likely it is that the value of the respective new knowledge can be understood and then quickly assimilated and applied by the employees within innovation transfer. A high absorptive capacity allows innovations in the form of new knowledge to be continuously integrated into the company knowledge base, so that learning from old knowledge is possible [16; 58] and isolated "knowledge islands" remain limited [59]. This aspect has a lasting influence on the integration phase of the innovation transfer, because only those employees who are generally capable of expanding their knowledge base are suitable to actively participate in the innovation transfer.

The existence of needed competences within the parent company is therefore one of the major aspects within the transfer process. If there is no knowledge within the field of the innovation in the corporate, this missing knowhow needs to be build up or externally sourced. However the existing competences do not need to be necessary within the receiving business unit. Using synergetic potential throughout the corporate is especially helpful within technological development projects. A needed requirement for that is the commitment of the management.

However a too comprehensive prior knowledge of the recipient context is harmful, because in this case both transfer parties would not be satisfied with the degree of change and they would question the importance of each other's work. The relationship between transfer success and prior knowledge can therefore be described as arcuate [50].

2) Organizational flexibility: Corporates are mainly based on long established corporate structure and processes. Especially for the development of incremental innovations, these structures help employees to proceed within the innovation process and develop innovation following a defined path. However rigid structures reduce the capability to react on unexpected events. In contrast to that, innovation in corporate incubators are mainly based on assumptions and risks. To be capable to react on changes within the innovation, corporate incubators mainly uses agile methods for the development. The organizational flexibility characterizes the ability of a corporate to react on short-term and to change established structures and processes flexible based on the transferred innovation. The organizational can therefore be described as either low or high flexible.

The organizational flexibility within the corporate is directly linked to the success of the transfer process. It is often difficult to assign the incubators output to existing internal process structures of the parent company [12] so that the integration of the current innovation project into the 
parent company is not well prepared and often fails. If the corporate is able to react on short notice, the existing structures and processes can be adapted based on the innovation. Depending on the innovation even a change within the established departments could be necessary. Furthermore a flexible and fast access to personal resources and the ability to allocate theses resources on short notice to a new task is elementary. Beside the capability to change existing structures and processes, the flexibility of thinking within the employees is another important aspect. Employees within the corporate with a high flexibility are more likely to be able to adapt to changes within their usual working surrounding. In total a high flexibility within the organization increases the speed within the transfer process.

If the flexibility is low within the corporate, more resources for the transfer process may be needed. Fitting organizational structures have to be created or adapt with a large amount of time. Furthermore the transfer processes need to be planned in more detail and in advanced and cannot be started on short notice at a later development stage.

3) Management support: The influencing factor management support displays the degree of support from the corporate management to the corporate incubator. It defines how great the commitment within the organization is for the activities of the corporate incubator. The management support is an important factor to reduce problems concerning the acceptance within the organization [16]. The management can be differentiated in top management which is more strategic oriented and the middle management, which focusses on the operative activities. Therefore the specifics of the influencing factor can be displayed as no support, support of the top management and support of the whole management.

Nonaka [60] as well as Takeuchi and Nonaka [61] underline the relevance of leadership to the success of innovation transfer. A high degree of support and participation from the management enables employees to meaningful bring their own experience in the daily business [62].

If the management support is high, and top management as well as middle management is involved, an adequate resource availability can be expected. The high prioritization within the corporate management structures increases the probability of transfer success [50].

By sharing information comprehensively and appropriately, managers can support open communication, so that knowledge is not misused as an instrument of power in an intransparent and monopolistic manner. All in all, this leadership transparency ensures a continuous flow of knowledge, as no conscious knowledge restrictions in the form of "silo mentalities" are built up and the corresponding transfer of innovation is hindered. The more intensively the employees feel informed and the sooner they receive transparent information, the more motivated they participate in the knowledge transfer [55] and the sooner a common understanding is developed. The identification of knowledge carriers on the part of the recipient context is also important. Managers are required to identify employees who are critical to success with their strategic knowledge areas and to make their knowledge available to all participants so that the required competencies can be called up. In this context, managers can act as knowledge activists and support knowledge transfer efforts. They act as catalysts that point the way for employees [63].

Experiences within consulting projects of the author show, that the management support is probably the most important influencing factor within the transfer process. If there is no management support for the innovation, the transfer process is likely to fail. Therefore management support should be seen as a mandatory factor to start the flow of the knowledge.

4) Corporate culture: Abstractly described, culture is defined by collectively shared, implicit as well as explicit norms of behavior, which are learned and passed on by the individuals of a social group. In the context of a business environment, it corresponds to a system of basic beliefs, values and norms that informally influence the actions of organizational members [64] Corporate culture therefore defines the culture which can be found throughout the corporate employees, especially the openness for new innovations is thereby addressed. It can be differentiated into innovation-inhibiting and innovationfriendly corporate culture.

The transfer of innovations is mainly influenced from the corporate culture. An innovation-inhibiting corporate culture can lead employees to resist against external innovation projects. In contrast to that an innovation-friendly culture especially promotes openness and motivates the trial of new things. The "clash of cultures" between the corporate incubator with its culture focusing on the aspects of creativity, risk as well as speed and the established culture of the corporate are one of the main challenges parent companies are facing these days within the cooperation [11].

An innovation-friendly culture promotes an intellectual exchange between the two entities. The employees within the corporate think of the corporate incubator more as a part of the corporate and are not afraid of possible new business opportunities identified within the incubator. Transferring innovation based on an innovation-friendly culture is therefore more easily due to the higher acceptance within the corporate.

An innovation-inhibiting culture is usually based on a more intense "silo mentality" throughout the different corporate departments. Reaching power and shaping its own profile is important within the organization. The corporate incubator is therefore mainly seen as competitor which will undermine the own business. The lack of acceptance throughout the corporate makes the transfer process more difficult. More barriers and more needed resources should be planned to fulfill the integration.

Consequently, this means that transfer partners with widely differing corporate cultures must invest considerable time and resources in order to achieve similar interaction patterns [41]. According to Buckley and Carter [46] only intensive communicative interaction between employees with similar motivation, attitudes and goals can reduce transfer barriers. In summary, the corporate culture shapes the basis of how motivated and open employees participate in a transfer project. 


\section{Comprehensive context}

As a comprehensive influencing factor which addresses the corporate incubator as well as the corporate, the compatibility of the innovation processes was determined (see figure 6).

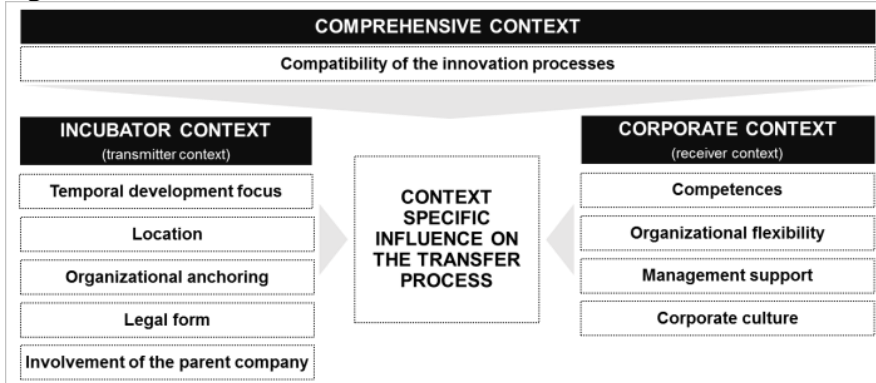

Fig. 6. Description model of context-specific factors influencing innovation transfer

1) Compatibility of the Innovation Processes: There are different approaches to handle the innovation process. On the one hand, there are sequentially rigid approaches, such as the mechanical stage-gate process structures. This process is defined by individual processing phases with their own structured activities and requirement targets, so-called stages, as well as so-called gates to examine these requirements [65]. Accordingly, specific information is collected for each phases and target success is tested sequentially [66]. On the other hand, there are agile methods that define themselves by iterative loops in an organic process structure and focus on high flexibility or greater uncertainty. Special about agile methods is that in contrast to the sequential stage gate process, different process steps are persecute at the same time and that there are no defined gates to pass. For the simplicity within this paper, it is assumed that parent companies work with a sequential stage gate process and corporate incubators use agile approaches. The compatibility of the innovation process is defined in this context as the degree in which the innovation process of the corporate and the corporate incubator are aligned and therefore can be further characterizes as aligned and not aligned.

An alignment of the innovation process between the two involved entities is important because it supports a smooth innovation transfer. If the processes of the corporate incubator and its parent company are not aligned, transfer problems can occur. For example innovations which are developed within an agile approach are hard to assign within the defined process structures of an established stage gate process due to its different development maturity [11]. The needed efforts to align the processes will lead to the need for more resources and a loss of innovation speed.

If the different processes are aligned, the compatibility of the innovation can already be an aspect within the creativity and development phases. Through the awareness of the existing structures the corporate incubator or the parent company can already prepare the transfer process at an early stage. By doing so, the transfer process can be done efficient in time, costs and resources.

However that does not mean that the incubator and the corporate need to have the same innovation process. Defined interfaces and a defined time schedule can also lead to an alignment of the different innovation processes.

\section{Overall presentation of the influencing factors}

A total of 10 influencing factors within the sender, receiver and the comprehensive context were identified, described and examined with regard to their relevance for innovation transfer on the basis of a comprehensive literature analysis and practical experience from the authors. Five factors were identified within the context of the corporate incubator, four within the context of the corporate and one in the comprehensive context. The factors are displayed with their detailed characteristics in morphological box in figure 7 .

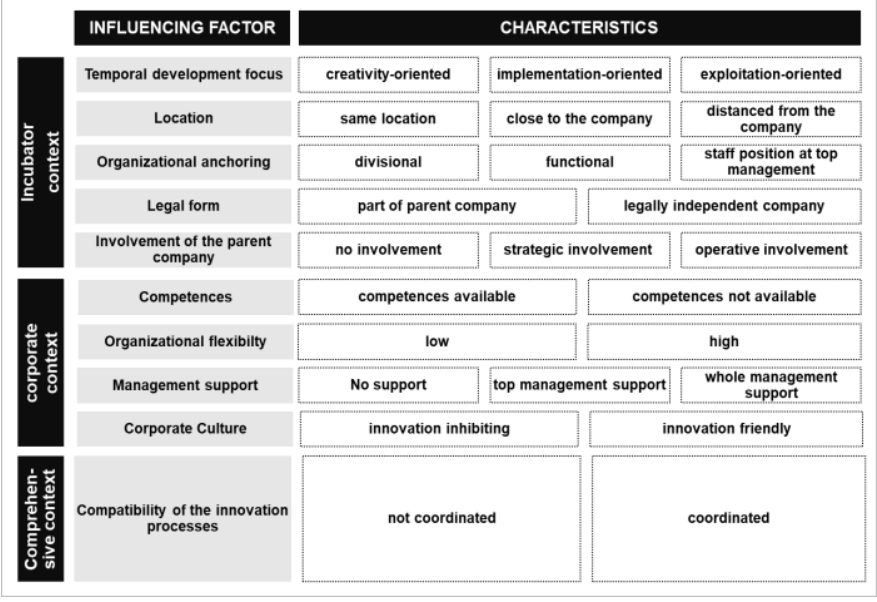

Fig. 7. Influencing factors and characteristics

\section{CONCLUSION \& FUTURE RESEARCH}

Established companies use corporate incubators to foster radical innovations outside the current business. Due to the long-term strategic fit to the corporate strategy, many of these "external" innovations are transferred from the corporate incubator to the parent company for ramp up and commercialization. However this innovation transfer is a major challenge for most of the corporates and so far not sufficiently addressed in scientific literature. The aim of the authors therefor is to develop a comprehensive model of innovation transfer from corporate incubators which includes all relevant aspects and allows corporates to situation specific define their transfer process. This publication displays a contribution to the model of innovation transfer and addresses the question which context specific influencing factors affect the transfer process between corporate incubators and its corporate.

Therefore a framework for the context factors influencing the transfer process was developed. The relevant entities according to the sender-receiver model are "corporate incubator" as sender and the "parent company" as receiver as well as an entity overlapping context. Within the different framework contexts 10 influencing factors were identified and analyzed for their transfer impact. Furthermore different characteristics of the influencing factors were described. These factors are based on an intensive literature study as well as practical experience of the authors through different consulting projects within the field of corporate incubators.

It was shown, that there are only a few specific influencing factors which are mainly influencing the transfer process. These factors need to be taken into account before a transfer process is started. Based on the specific factors, each transfer process needs to be designed individually. The present work 
thus makes an important contribution to the understanding of the practical problem, as well as to the academic theory deficit in the research field of innovation transfer from corporate incubators to their parent companies.

Future research will be followed within this topic. To develop a comprehensive model of innovation transfer, the author will identify different design options for the transfer process and will assess theses based on their impact concerning the context specific factors. Furthermore a mathematic logic to derive recommendation for the transfer design based on all relevant factors will be needed.

\section{REFERENCES}

[1] Schuh, G.; Klappert, S.; Orilski, S. (2010): Technologieplanung, p. 171-222, in: Schuh, G.; Klappert, S.: Technologiemanagement, Springer, Heidelberg

[2] Chang, Y.-C.; Chang, H.-T.; Chi, H.-R.; Chen, M.-H.; Deng, L.-L. (2012): How Do Established Firms Improve Radical Innovation Performance? The organizational capabilities view. In: Technovation 32 (7-8), S. 441-451.

[3] Leifer, R.; O'Connor, G. C.; Rice, M. (2001): Implementing radical innovation in mature firms. In: Academy of Management Executives 5 (3), S. 102-112.

[4] Birkinshaw, J.; Hill, S. A. (2005): Corporate Venturing Units. Vehicles for Strategic Success in the New Europe. In: Organizational Dynamics 34 (3), S. 247-257.

[5] Hill, S. A.; Birkinshaw, J. (2014): Ambidexterity and Survival in Corporate Venture Units. In: Journal of Management 40 (7), S. 1899 1931.

[6] Ahmad, A. J.; Thornberry, C. (2016): On the structure of busines incubators. De-coupling issues and the mis-alignment of managerial incentives $29 \quad(10)$ Online verfügbar unter https://doi.org/10.1007/s10961-016-9551-y.

[7] Christensen, C. M. (2015): The Innovator's Dilemma. When New Technologies Cause Great Firms to Fail. Boston: Harvard Business Review Press.

[8] Gassmann, O.; Becker, B. (2006): Towards a resource-based view on corporate incubators. In: International Journal of Innovation Management 10 (1), S. 19-45.

[9] Bullinger, H.-J.; Spath, D.; Warnecke, H.-J.; Westkämper, E. (2008): Handbuch Unter-nehmensorganisation. Strategien, Planung, Umsetzung.. 3rd Aufl. Berlin: Springer-Verlag.

[10] Schuh, G.; Wellensiek, M.; Dölle, C.; Vogt, F.; Schwarberg, T.; Ays, Johanna (2018): Consortium Benchmarking 2018 >>Agile Invention $<<$. Fraunhofer Institute for Production Technology. Aachen, not published.

[11] Schuh, G.; Vogt, F.; Maurer, D. (2019): Transfer von Innovationen aus firmeninternen Inkubatoren, White Paper - Empirische Studie, Aachen, Fraunhofer IPT

12] Rubin, T. H.; Aas, T. H.; Stead, A. (2015): Knowledge flow in Technological Business Incubators. Evidence from Australia and Israel. In: Technovation 41. - 42., S. 11-24.

[13] Shannon, C. Elwood; Weaver, W. (1964): The Mathematical Theory of Communication: Dissertation, University of Illinois.

[14] Albrecht, S.; Lambke, G. (2002): Über die Verteilung von Wissen in Organisationen. In: Wissensmanagement 4 (1), pp. 53-55.

[15] Probst, G. J. B.; Robbery, S. P.; Romhardt, K. (2012): Wissen managen. Wie Unternehmen ihre wertvollste Ressource optimal nutzen. 7th Aufl. Wiesbaden: Springer Gabler. Available online at http://dx.doi.org/10.1007/978-3-8349-4563-1.

[16] Krogh, G. von; Köhne, M. (1998): Der Wissenstransfer in Unternehmen: Phasen des Wissenstransfers und wichtige Einflussfaktoren. In: Die Unternehmung 52 (5-6), p. 235-252.

[17] Zeppin, M. (2013): Wissenstransfer. Methoden, Anforderungen und Gestaltungsmöglichkeiten zur Sicherung und Weitergabe des Wis-sens/ Michael Zeppin. Saarbrücken: VDM-Verl. Müller, 2013

[18] Polanyi, M. (1966): The Tacit Dimension. London: Doubleday.

[19] Meißner, D. (2001): Wissens- und Technologietransfer in nationalen Innovationssystemen: Dissertation, Technical University of Dresden.

20] Geschka, H. (1988); Wünnenberg, H.: Innerbetrieblicher TechnologieTransfer. Eine Chance. 1. Aufl. Köln: Verlag TÜV Rheinland, 1988
[21] Fischer, M. (2011): Hochschulpräinkubatoren und ihr Einfluss auf Unternehmensgrün-dungen in der Planungsphase. Eine qualitativempirische Analyse: Dissertation, Leuphana University Lüneburg.

[22] Becker, B. (2003): Corporate Incubators - Potentials, Typology and Principles. Bamberg: Difo-Druck GmbH (also dissertation, University of St. Gallen).

[23] Burns, T.; Stalker, G. M. (2001): The Management of Innovation. Erstdruck 1961. Oxford: Oxford University Press.

[24] Boutellier, R.; Ullman, F.; Schreiber, J.; Naef, R. (2008): Impact of office layout on communication in a science-driven business. In: R\&D Management 38 (4), S. 372-391.

[25] Lühring, N. (2007): Innovationsfördernde Organisationsstrukturen unter Berücksichti-gung früher Innovationsphasen. In: C. Herstatt and B. Verworn (ed.): Management der frühen Innovationsphasen Grundlagen - Methoden - Neue Ansätze. 2nd Aufl. Wiesbaden: GablerVerlag, pp. 135-164

[26] Gaida, K. (2011): Gründen 2.0. Erfolgreiche Business-Inkubation mi neuen Internet-Tools. Wiesbaden: Gabler publishing house.

[27] Wagner, P.; Wosch, S. (2015): Corporate Incubators Nurturing Innovation Potential. In: Performance 7 (4), S. 26-33.

[28] Zedtwitz, M. von (2003): Classification and management of incubators: Aligning strategic objectives and competitive scope for new business facilitation. In: International Journal of Entrepreneurship and Innovation Management. 3 (1-2), S. 176-196.

[29] Zedtwitz, M. von (2005): Inkubatoren für die Kommerzialisierung neuer Technologien. In: S. Albers and O. Gassmann (ed.): Handbuch Technologie- und Innovationsmanagement: Strategie - Umsetzung Controlling. Wiesbaden: Gabler-Verlag, p. 547-564.

[30] Schuh, G.; Lau, F.; Zimmermann, R.; Vogt, F. (2017b): Configuration of Corporate Incubators. In: Proceedings of the Portland International Conference on Management of Engineering and Technology (PICMET), S. 1-10

[31] Simoudis, E. (2014): Using Corporate Incubators and Accelerators To Drive Disruptive Innovation. Re-Imagining Corporate Innovation with a Silicon Valley Perspective. Online verfügbar unter https://corporateinnovation.co/2014/09/08/additional-considerations-for-corporateincubators-and-accelerators/, zuletzt geprüft am 11.08.2018.

[32] Ebers, M. (2017): Organisationsmodelle für Innovation. In Schmalenbach's Zeitschrift für betriebswirtschaftliche Forschung 69 (1), pp. 81-109.

[33] Stringer, R. (2000): How to manage radical innovation. In: California Management Review 42 (4), S. 70-88.

[34] Mes, F. (2011): Internal Corporate Venturing zur Steigerung der Innovationsfähigkeit etablierter Unternehmen. Ein konzeptioneller Ansatz zur Übertragung der Instrumente der Venture-Capital-Industrie Wiesbaden: Gabler Verlag (also dissertation, Bergische Universität Wuppertal)

[35] Hauschildt, J.; Salomo, S.; Schultz, C.; Kock, A. (2016): Innovationsmanagement. Munich: Vahlen.

[36] Rysiew, P. (2007; 2016): Epistemic Contextualism. In: Standford Encyclopedia of Philosophy. Available online at https://plato.stanford.edu/entries/contextualism-epistemology/, last checked on 25.06.2018.

[37] Ulrich, U.; Hill, W. (1976): Wissenschaftstheoretische Grundlagen der Betriebswirtschaftslehre. In: Wirtschaftswissenschaftliches Studium: Zeitschrift für Ausbildung und Hochschulkontakt 5 (7-8), pp. 304-309.

[38] Ulrich, H. (1984): Management. In: T. Dyllick and G. Probst (Hg.): Die Betriebswirtschaftslehre als Anwendungsorientierte Sozialwissenschaft. Stuttgart: Paul Haupt Publishing House, pp. 168 199.

[39] Ulrich, P.; Hill, W. (1979): Wissenschaftstheoretische Aspekte ausgewählter betriebs-wirtschaftlicher Konzeptionen.. In: H. Raffée and B. Abel (ed.): Wissenschaftstheoreti-sche Grundlagen der Wirtschaftswissenschaften. Munich: Vahlen, pp. 53-62.

[40] Schuh, G.; Vogt, F.; Lau, F.; Bickendorf, P. (2017c): Concept of Innovation Transfer from Corporate Incubators. In: 2017 Portland Internati-onal Conference on Management of Engineering and Technology (PICMET). Portland, OR, 09.07.2017 - 13.07.2017. IEEE, 2017, S. 1-11

[41] Rohrlack, C. (2009): Reverse Technology Transfer in Multinationalen Unternehmen. Bedingungen und Gestaltungsmöglichkeiten. Kiel: Gabler-Verlag.

[42] Lau, F. S. (2019): Modell zur typenbasierten Gestaltung von firmeninternen Inkubatoren: Dissertation in preparation, RWTH Aachen. 
[43] Brose, P. (1982): Planung, Bewertung, und Kontrolle technischer Innovationen.. Berlin: E. Schmidt.

[44] Seeger, B. (2014): Erfolgsstrategien zur Gestaltung von Innovationsprozessen. Eine empirische Analyse mittelständischer Innovationssysteme. Wiesbaden: Gabler publishing house.

[45] Verworn, B.; Herstatt, C. (2007): Bedeutung und Charakteristika der frühen Phasen des Innovationsprozesses. In: C. Herstatt and B. Verworn (ed.): Management der frühen Innovationsphasen. Grundlagen - Methoden - Neue Ansätze. 2nd Aufl. Wiesbaden: Gabler-Verlag, pp. 3-22.

[46] Buckley, P. J.; Carter, M. J. (2004): A Formal Analysis of Knowledge Combination in Multinational Enterprises. In: Journal of International Business Studies 35 (5), S. 371-384.

[47] Welge, M. K. (1981): The Effective Design of Headquarter-Subsidiary Relationship in German MNCs. In: L. Otterbeck (Hg.): The Management of Headquarters. Subsidiary Relationships in Multinational Corporations. Aldershot: Gower, S. 79-106.

[48] Athanassiou, N.; Nigh, D. (2000): Internationalization, tacit knowledge and the top management teams of MNCs. In: Journal of International Business Studies 31 (3), S. 471-487.

[49] Meyer, A. de (1991): Tech Talk: How Managers are Stimulating Global R\&D Communication. In: Sloan Management Review 32 (3), S. $49-58$.

[50] Cummings, J. L.; Teng, B.-S. (2003): Transferring R\&D knowledge. The Key Factors Affecting Knowledge Transfer Success. In: Journal of Engineering and Technology Management. 20 (1-2), S. 39-68.

[51] Witte, E. (1973): Organisation für Investitionsentscheidungen. Das Promotorenmodell. Göttingen: Otto Schwartz \& Co.

[52] Swink, M. (2000): Technological innovativeness as a moderator of new product design integration and top management support. In: Journal of Product Innovation Management 17 (3), S. 208-220.

[53] Sandberg, B.; Aarikka-Stenroos, L. (2014): What makes it so difficult? A systematic review on barriers to radical innovation. In: Industrial Marketing Management 43 (8), S. 1293-1305.

[54] Vahs, D. (2015): Organisation. Ein Lehr- und Managementbuch. 9. Aufl. Stuttgart, Germany: Schäffer-Poeschel Publishing House. Available online http://site.ebrary.com/lib/alltitles/docDetail.action?docID=11093126.

[55] Schröder, K. A. (2003): Mitarbeiterorientierte Gestaltung des unternehmensinternen Wissenstransfers. Identifikation von Einflussfaktoren am Beispiel von Projektteams. Wiesbaden: Deutscher Universitäts-Verlag (also Dissertation, Technical University HamburgHarburg).

[56] Cohen, W. M.; Levinthal, D. A. (1990): Absorptive Capacity: A New Perspective on Learning and Innovation. In: Administrative Science Quarterly 35 (1), S. 128-152.

[57] Hamel, G. (1991): Competition for competence and inter-partner learning within international strategic alliances. In: Strategic Management Journal 12 (Special Issue), S. 83-103.

[58] Inkpen, A. C.; Crossan, M. M. (1995): Believing is Seeing: JointVentures and Organization Learning. In: Journal of Management Studies 32 (5), S. 595-618.

[59] Probst, G. J. B.; Robbery, S. P.; Romhardt, K. (2006): Wissen managen. Wie Unternehmen ihre wertvollste Ressource optimal nutzen. Fifth Aufl. Wiesbaden: Gabler publishing house.

[60] Nonaka, I. (1992): How Japanese corporations generate knowledge. In: Harvard Business Manager 11 (2), p. 95-103.

[61] Takeuchi, H.; Nonaka, I. (2012): The Organization of Knowledge. How Japanese companies make use of an idle resource. 2nd Aufl. Frankfurt am Main: Campus-Verlag.

[62] Zugaro, E. G.; Zugaro, C. G. (2017): The listening leader. How to drive performance by using communicative leadership. Harlow: Pearson Education.

[63] Nonaka, I.; Krogh, G. von; Voelpel, S. (2006): Organizational Knowledge Creation Theory. Evolutionary Paths and future Advances. In: Organization Studies 27 (8), S. 1179-1208.

[64] Schein, Edgar H. (2010): Organizational culture and leadership. 4. Aufl. San Francisco: Jossey-Bass.

[65] Cooper, R. G. (1986): Winning at new products. Reading: AddisonWesley.

[66] Badura, A. (2015): Stafe-Gate-Prozess. Hochschule Landshut. Available online at https://www.controllingwiki.com/de/index.php/Stage-Gate-Prozess, last checked on 18.07.2018.
[67] Petersen, C. (2012): Laterale Technologietransferprojekte in multinationalen Unterneh-men. Kontext, Gestaltung und Effizienz. Wiesbaden: Gabler Verlag (also dissertation, Christian-AlbrechtsUniversität zu Kiel)

[68] Hansen, M. T. (1999): The Search-Transfer Problem: The Role of Weak Ties in Sharing Knowledge. In: Administrative Science Quarterly 44 (1), S. 82-111.

[69] Solis, B. (2015): The Innovation Game. Why and How Businesses are Investing in Innovation Centers? Why Should Companies Launch Innovation Centers? Hg. v. Capgemini Consulting Altimeter. Online verfügbar unter https://www.capgemini.com/consulting/resources/theinnovation-game/, zuletzt geprüft am 03.08.2018. 